Literary Research

www.ijrap.net

\title{
INTERPRETATION OF AYURVEDIC TERMINOLOGIES FROM BIOSTATISTICAL PERSPECTIVE IN RESEARCH
}

\author{
Athikajan $^{1 *}$, Shreevathsa ${ }^{2}$, Rajendra $\mathrm{V}^{3}$
}

${ }^{1}$ Lecturer, Department of Basic principles, JSS Ayurveda Medical College, Mysore, Karnataka, India

${ }^{2}$ Assistant Professor, Department of Basic principles, Govt Ayurveda Medical College, Mysore, Karnataka, India

${ }^{3}$ Professor, Department of Kayachikitsa, Govt Ayurveda Medical College, Mysore, Karnataka, India

Received on: 03/12/12 Revised on: 20/01/13 Accepted on: 20/02/13

\author{
*Corresponding author \\ E-mail: drathikajan@gmail.com \\ DOI: 10.7897/2277-4343.04229 \\ Published by Moksha Publishing House. Website www.mokshaph.com \\ All rights reserved.
}

\section{ABSTRACT}

Any branch of science demands precision for its development, and so does the medical science. For precision facts, observations or measurements have to be expressed in a figure, which is termed as statistics. Everything in medicine be it a research, diagnosis or treatment, depends on numbers or measurement. Ayurvedic scholars had given due regard to the importance of statistical methods. The mentioning of term 'sankhya' and 'maana' in the literature of Ayurveda itself indicates the importance given to numbers and measurement. This work aims at interpreting different terminologies of Ayurveda from the Bio-statistical perspective. For this purpose relevant information were collected from the various literatures of Ayurveda and contemporary science and interpretation was done on each statistical terminology. The statistical methods which were used by the ancient Indian seers are in practice for a long time, but it is the need of the hour to explore them with some new terminologies of contemporary science, to standardize the quality of research in Ayurveda. Hence by this work it would be helpful to conclude that Statistical methods which is considered as a recent advancement was in use since ages.

Key words: Biostatistics, Ayurveda, Sankhya, Maana

\section{INTRODUCTION}

The quest for knowledge generates out of inquisitiveness which ultimately leads to understanding of various phenomena. In all the branches of earlier ancient sciences, the methods adopted to increase understanding or knowledge base, were mainly experiential, observational and inferential. In the process of development of knowledge the perspective regarding a scientific concept may change based on the logical interpretations and experimental evidences. Ayurveda is no exception to the rule where the knowledge was developed according to the above mentioned system.

Therefore to find the facts and to review where Ayurveda does stand today, in terms of research process, some of the methods which are reflected in Ayurveda are elaborated below.

Biostatistics is the term used when tools of statistics are applied to the data that is derived from biological sciences such as medicine. Biostatistics covers applications and contributions not only from the areas of health, medicine and nutrition but also from fields such as agriculture, genetics, biology, biochemistry, demography, epidemiology, anthropology and many others ${ }^{1}$. Research involves precise observation and accurate description as well as comparisons. This is possible only if the information is collected in a scientifically designed pattern. Statistical methods help the research worker to suitably plan for the collection of desired information through appropriate statistical designs.

Statistical quantities serve as indices for the measurement of health of a community in terms of rates and ratios of fatalities, morbidities, mortalities, health facilities and their availability or usage and so on. These indicators are useful in comparing the health status of a community or group from one place to the other or from one season or period to the other. They also help in analysing and interpreting the influence of environmental, social, economical, seasonal and other numerous factors on health of a community.

Statistics is the science of collecting and analysing significant numerical data. Numerical means to deal with numbers.

In this regard all the Brihatrayees (three important Ayurvedic books) particularly in Charaka Samhita, numerical values for a particular data viz five mahabhutas (basic elements), three doshas(humours), six upakramas (modalities of treatment), three Rogamargas (routes of disease) and eight Mahagadas etc are explained.

In Charaka samhita there is a direct reference defined and utility described for the presence of the term Sankhya which refers to the complete knowledge which forms the foundation for exploration of new concepts ${ }^{2}$. The term Sankhya is used in many places i.e. while explaining indriya panchaka (sense organs with their faculties), rasa dosha vikalpa (inter-relation between diet and doshas) the concept of sankhya is used. The whole chapter of Charaka samhita sutrasthana, ashtodareeya adhyaya, $18^{\text {th }}$ chapter, is based on Sankhya itself.

Again it is said that, Sankhyaa syaad ganitam and Sankhya lakshayati sankhyaa iti eka dwi trayaadi in which the term sankhya refers to mathematics and expression in numericals ${ }^{3}$.

Even the concepts like the karma, kala and yoga basti (different types of enema therapies) are classified based on numbers. While mentioning about virechana vegas (maaniki and vaigiki) and vamana vegas (purificatory procedures) the concept of sankhya is used. 
Understanding of common statistical terms from Ayurvedic perspective

One of the methods to have the knowledge of scientific basis of Ayurvedic concepts is to interpret statistical terms from Ayurvedic perspective.

\section{Medical statistics}

Medical statistics is the application of statistics in the field of medicine i.e.in study of disease, defect, injury and treatment. This concept is highlighted in the first chapter of Charaka samhita which says causative factors, signs and symptoms and treatment are the trisutra for individuals both healthy and diseased ${ }^{4}$, the knowledge of which is eternal and provides wellness.

Vikrutitaha pariksha (examination of morbidity) highlights that the patient is to be examined for the vikruti (morbid manifestations). These morbid manifestations are to be examined with reference to the specific causative factors, doshas and dhatus (tissues) involved in the pathogenesis, constitution of the individual, habitat, season and strength and also the symptoms of the disease. Without determining the strength of the above mentioned factors it is not possible to obtain the knowledge regarding the intensity of the disease.

\section{Health statistics}

It is the application of statistical methods in preventive, promotive and curative aspects of life. The concept of health as mentioned in Sushruta samhita says 'a healthy person is one whose bodily humours and digestive fire are in equilibrium, whose functional activities of the tissues and excretory systems are in balance, and the soul, senses and mind feel well' ${ }^{5}$. If this is maintained then one can prevent the diseases and promote the health.

\section{Tabulations}

Tabulations are the devices for representing data from a mass of statistical data. The concepts of Ganas (collections of drugs) like salasaradi gana, aragvadhadi gana ${ }^{6}$ explained in Sushruta samhita, 50 maha kashayas (medicated decoctions) ${ }^{7}$, lakshanas of Prakruti (signs of bodily constitution) ${ }^{8}$ explained in Charaka samhita represents tabulation forms.

\section{Data}

Data refers to a set of values recorded on one or more observational units. The two types of data are qualitative data and quantitative data. Qualitative data is also called as the 'attribute' as it is attributed to some qualities.

The concept of guna (property) where each guna is attributed with specific quality can be considered under Qualitative data. For example, guru guna (heaviness) is attributed with brumhana quality (nourishing therapy). If any dravya (drug) is possessing brumhana quality then it is said to be having guru guna. Quantitative data is obtained by Measurement (parimaanam punarmaanam) ${ }^{9}$ and Counting (ganana) ${ }^{10}$.

\section{Measure of variability}

It is also called as the measure of dispersion. It describes about the spread or scatteredness of individual observation around the central tendency ${ }^{11}$. Range is a measure of variability which defines the normal limits of a biological characteristic ${ }^{12}$.

The range for swastha (healthy) is sushtum nirvikaaratvena avatishtati (state of being healthy without illness) ${ }^{13}$ to the equilibrium of bodily humours, digestive fire, balance in functional activities of the tissues and excretory systems, and wellness of the soul, senses and mind $^{14}$. The concept of Ashta nindita purusha (eight contraindicated persons for treatment) atidheerga (Gigantism), atihrusva(dwarfism), atisthoola (obese), atikrusha (lean) ${ }^{15}$ etc describes the deviation from the normalcy.

\section{Sampling method}

In sampling a small sample is taken from a large number of population and the concepts are generalized and applied to the whole population.

- Generalization can be valid only if the observed series or sample is representative of a large mass or the whole for which the concept of samanya (generality) is applicable. (samanyam ekatvakaram) ${ }^{16}$

- Selection or bias must be ruled out in any estimate or experiment to get the true value for the whole (lakshanas of apta) $^{17}$

\section{Correlation}

The relationship or association between two quantitatively measured or continuous variables is called correlation ${ }^{18}$. In Ayurveda there are many references which say about the concept of correlation.

- The percentage of correlation of agni (digestive fire) in case of arsha (hemorrhoids), atisara (diarrhea), Grahani (irritable bowel syndrome) and udara (ascites).

- The concept of vyadhi sankara wherein if anubandhya is given treatment the anubandha also gets treated ${ }^{19}$.

- Karya karana sambandha wherein there is mutual relationship between cause (karana) and effect (karya).

- The concept of tara-tama bhavas (permutation and combination) where the strongest one will produce the disease ${ }^{20}$.

\section{Designing of experiment}

Design of research work or experimental model is the clear conception in advance, after selection of the problem, or the requirements for conducting the whole work upto its desired results. This is evident the quotation which says one should be thorough with the knowledge by interpreting and analyzing in all possible directions and then carry out the work ${ }^{21}$.

\section{Vital statistics}

It is the data which gives quantitative information of vital events. i.e. migration, births, marriages and death in a given population. Expectancy of longevity i.e, alpayu and dirghayu lakshanas (symptoms of short and long life span) ${ }^{22}$, kala and akala mrutyu (timely and untimely death $)^{23}$ gives the knowledge about the vital statistics. The number of people exposed to disease, the number of people fall ill is evident by the references in janapadodhwamsaniya adhyaya (chapter on epidemic diseases) of Charaka samhita. 


\section{Measurement (Maana)}

Both biometry and Ayurveda deal with the measurement of life. The concepts like pramana sharira (measurement of body), anjali pramana (measurement by palms), anguli pramana (measurement by finger breadth) deals with measurement. The measurement of life as hitayu, ahitayu, sukhayu and dukhayu shows the importance of maana. Vimana sthana of Charaka Samhita is named so because it emphasizes on accuracy i.e. maana ${ }^{24}$.

Significance is also given for consideration of various measurements in accurate diagnosis and successful treatment. Fractions and multiplications are useful in prescribing medicines and food. Rashi (amount of food) viz: sarvagraha (total quantity) and parigraha(quantiy of individual component) is an example of fraction.

Vada margas (rules and ways of debate) ${ }^{25}$ is the unique concept of Ayurveda which deals entirely with statistics and research.

- Pratignya- Setting up of hypothesis

- Prayojana- Alternative hypothesis

- Samshaya- Probability

- Siddhanta- Concept established

\section{DISCUSSION}

Statistics is a study of knowledge which deals with different methods of collection, classification, presentation, analysis and interpretation of data. Statistical application is very important in the field of research. It helps:

- To simplify or to condense the huge data viz: collection of the symptoms of various diseases.

- To test the hypothesis i.e. revalidation of the concept mentioned in the books of Ayurveda.

- To draw the conclusions- Based on the conducted experiments or based on previous studies, conclusions are drawn and if necessary some recommendations are suggested.

- To predict the future aspects.

Ayurveda is in practice from time immemorial in serving humanity by its unique preventive and curative approach. This knowledge covering the entire gamut of health which in turn had occupied the place of core system of medicine is being viewed in a skeptic way about its authenticity because it lacks documentation of research work. But a scan through the literature of Ayurveda says that a lot of research work were carried out in Ayurveda but because of lack of facilities of writing, printing, storage it was not documented and only conclusion of the research was documented as siddhantas (postulates). Moreover Ayurveda had faced a downfall in the past due to foreign invasion, historical and religious causes leading to the destruction of lot of valuable Ayurvedic knowledge/literature. There are references which states that Brahma samhita had contained 1000 chapters and 1 lakh slokas ${ }^{26}$ but it is not available and many other such Ayurvedic samhitas are incompletely available or not available.

Ayurveda gives importance for having sound knowledge of other allied sciences also and ganita shastra (science of mathematics) being prevalent since ages has its influence on Ayurveda also. The statistics tells about condensation and systematic presentation of data which is very well explained in tantrayuktis and also shastra pariksha in Charaka samhita. The definition of Siddhanta says 'Siddhanta is the one which is the conclusion obtained after repeated testing by various persons'. This itself indicates that lot of research was done to come to a conclusion and here the statistics test of significance holds good. The detailed study and understanding of samhitas of Ayurveda reveals that a lot of statistical methods were used in those periods.

\section{Scope and limitations}

For proper use of statistics or statistical methods, it is good and necessary to know the scope and limitations in the field of health, nutrition, medical, biochemical, anthropological and biologicalsciences. One of the outstanding features of human being is that no two individuals are exactly alike. Even identical twins become distinguishable due to environmental influences. Variations are present not only between individuals but also within the individuals from time to time. Some of the factors contributing to variations and uncertainties in health are biological variability's, observer variability's, instrument variability's and environmental variability's.

By understanding the individual constitution of every individual, one can know which food and drink and what type of job, exercise are appropriate for maintaining their health. If the daily activities, diet, occupation and behaviour are not adjusted to balance this, then this constitutional humour will increase, thus giving rise to its characteristic diseases. If the constitution is known then herbs, diet and other regimens including yogic postures can be advised correctly both for disease treatment and to promote longevity. Hence Ayurveda has emphasised on personalised treatment.

According to Ayurveda, every individual is unique. Not only each individual has different size and shape, their physiological and even psychological characters are different. The dasha vidha pareeksha (ten methods of examination of patients $)^{27}$ aims at knowing the strength and intensity of morbidity (baladosha pramana jnana). So, Prakruti (Physical constitution), Vikruti (Morbidity), Sara (Excellence of dhatus), Samhanana (Compactness of Organs), Pramana (Measurement of the organs of the body), Satmya (Homologation), Sathva (Psychic constitutions), Aharashakti (Power of intake and digestion of food), Vyayama Shakti (Power of performing exercises) need to be examined in order to ascertain the person's strength and the intensity of the Malady. These factors vary from individual to individual leading to the increased number of variables. Among these above factors some of them are graded as pravara/ madhyama/ avara which again lead to variations in obtaining accurate results. Hence it becomes difficult for an Ayurvedic research scholar to apply statistical methods in research. In majority of the diseases, the lakshanas are subjective than objective. Hence it is difficult to apply the statistical parameters of the present science while conducting research in Ayurveda which involves lots of variables. 


\section{CONCLUSION}

The thorough understanding of Ayurvedic texts reveals that the statistical methods were used in those times. Though the tools used were different, the approach was same. To come to a final conclusion and accept the concepts as siddhantas proper research protocol was adopted after thorough scrutinisation. It is difficult to apply the statistical parameters of the present science in Ayurvedic research because of the multiplicity of the variables and needs modifications with Ayurvedic approach. Standardization of the variables like prakruti, agni, bala, koshta etc will help Ayurvedic scholars to get accurate results and hence global acceptance of Ayurveda as authentic science.

\section{REFERENCES}

1. Mahajan BK. Methods in Biostatistics. $7^{\text {th }}$ ed. New Delhi: Jaypee brothers medical publishers (p) ltd; 2010.

2. Vaidya Harish Chandra singh kushwaha, Reprint ed, Charaka Samhita; Ayurveda dipika's Ayushi hindi commentary; Vol I; Sootra sthana; Snehadhyaya: Chapter 13, Verse 3. Varanasi: Chaukhambha Orientalia, 2009; p. 197

3. Vaidya Harish Chandra singh kushwaha, Reprint ed, Charaka Samhita; Ayurveda dipika's Ayushi hindi commentary; Vol I; Sootra sthana; Atreyabhadrakapiya adhyaya: Chapter 26, Verse 32. Varanasi: Chaukhambha Orientalia, 2009; p. 379

4. Vaidya Harish Chandra singh kushwaha, Reprint ed, Charaka Samhita; Ayurveda dipika's Ayushi hindi commentary; Vol I; Sootra sthana; Dheerganjivitiya adhyaya: Chapter 1, Verse 24. Varanasi: Chaukhambha Orientalia, 2009; p. 10

5. Acharya YT, Acharya NR; Reprint ed; Sushruta Samhita of Sushruta; Sootra sthana; Doshadhatukshayavruddhivijnaniya adhyaya: Chapter 15, Verse 41. Varanasi, Chaukhamba Surabharati Prakashan, 2010; p. 75.

6. Acharya YT, Acharya NR, Reprint ed; Sushruta Samhita of Sushruta; Sootra sthana; Doshadhatukshayavruddhivijnaniya adhyaya: Chapter 38, Verse 48. Varanasi, Chaukhamba Surabharati Prakashan, 2010; p. 168.

7. Vaidya Harish Chandra singh kushwaha, Reprint ed, Charaka Samhita; Ayurveda dipika's Ayushi hindi commentary; Vol I; Sootra sthana; Shadvirechanashatashritiya adhyaya: Chapter 4, Verse 8. Varanasi: Chaukhambha Orientalia, 2009; p. 59

8. Vaidya Harish Chandra singh kushwaha, Reprint ed, Charaka Samhita; Ayurveda dipika's Ayushi hindi commentary; Vol I; Vimana sthana; Rogabhishagjitiya adhyaya: Chapter 8, Verse 1617-18. Varanasi: Chaukhambha Orientalia, 2009; p. 688

9. Vaidya Harish Chandra singh kushwaha, Reprint ed, Charaka Samhita; Ayurveda dipika's Ayushi hindi commentary; Vol I; Sootra sthana; Atreyabhadrakapiya adhyaya: Chapter 26, Verse 34; p: 378

10. Vaidya Harish Chandra singh kushwaha, Reprint ed, Charaka Samhita; Ayurveda dipika's Ayushi hindi commentary; Vol I; Sootra sthana; Atreyabhadrakapiya adhyaya: Chapter 26, Verse 32; p: 378

11. Mahajan BK. Methods in Biostatistics. $7^{\text {th }}$ ed. New Delhi: Jaypee brothers medical publishers(p) ltd; 2010. p 57

12. Mahajan BK. Methods in Biostatistics. $7^{\text {th }}$ ed. New Delhi: Jaypee brothers medical publishers(p) ltd; 2010. p 57
13. Vaidya Harish Chandra singh kushwaha, Reprint ed, Charaka Samhita; Ayurveda dipika's Ayushi hindi commentary; Vol I; Sootra sthana; Matrashiitiya adhyaya: Chapter 5, Verse 13(comm). Varanasi: Chaukhambha Orientalia, 2009; p. 76

14. Acharya YT, Acharya NR, Reprint ed; Sushruta Samhita of Sushruta; Sootra sthana; Doshadhatukshayavruddhivijnaniya adhyaya: Chapter 15, Verse 41. Varanasi, Chaukhamba Surabharati Prakashan, 2010; p. 75.

15. Vaidya Harish Chandra singh kushwaha, Reprint ed, Charaka Samhita; Ayurveda dipika's Ayushi hindi commentary; Vol I; Sootra sthana; Ashtouninditiya adhyaya: Chapter 21, Verse 3. Varanasi: Chaukhambha Orientalia, 2009; p. 309

16. Vaidya Harish Chandra singh kushwaha, Reprint ed, Charaka Samhita; Ayurveda dipika's Ayushi hindi commentary; Vol I; Sootra sthana; Dheerganjivitiya adhyaya: Chapter 1, Verse 45. Varanasi: Chaukhambha Orientalia, 2009; p. 16

17. Vaidya Harish Chandra singh kushwaha, Reprint ed, Charaka Samhita; Ayurveda dipika's Ayushi hindi commentary; Vol I; Sootra sthana; Tisraishaniya adhyaya: Chapter 11, Verse 18 Varanasi: Chaukhambha Orientalia, 2009; p. 162

18. Mahajan BK. Methods in Biostatistics. $7^{\text {th }}$ ed. New Delhi: Jaypee brothers medical publishers(p) ltd; 2010. p. 170

19. Vaidya Harish Chandra singh kushwaha, Reprint ed, Charaka Samhita; Ayurveda dipika's Ayushi hindi commentary; Vol I; Vimana sthana; Roganika vimana: Chapter 6, Verse 11. Varanasi: Chaukhambha Orientalia, 2009; p. 639

20. Vaidya Harish Chandra singh kushwaha, Reprint ed, Charaka Samhita; Ayurveda dipika's Ayushi hindi commentary; Vol I Sootra sthana; Kiyantashirasiya adhyaya: Chapter 17, Verse 41-44 Varanasi: Chaukhambha Orientalia, 2009; p. 263

21. Vaidya Harish Chandra singh kushwaha, Reprint ed, Charaka Samhita; Ayurveda dipika's Ayushi hindi commentary; Vol I; Vimana sthana; Trividharogavisheshavijnaniya vimana: Chapter 4, Verse 10. Varanasi: Chaukhambha Orientalia, 2009; p. 639

22. Acharya YT, Acharya NR, Reprint ed; Sushruta Samhita of Sushruta; Sootra sthana; Aaturopakramaniya adhyaya: Chapter 35, Verse 6-11. Varanasi, Chaukhamba Surabharati Prakashan, 2010; p. 149 .

23. Vaidya Harish Chandra singh kushwaha, Reprint ed, Charaka Samhita; Ayurveda dipika's Ayushi hindi commentary; Vol I; Sharira sthana; Shariravichaya shaarira : Chapter 6, Verse 28. Varanasi: Chaukhambha Orientalia, 2009; p. 841

24. Vaidya Harish Chandra singh kushwaha, Reprint ed, Charaka Samhita; Ayurveda dipika's Ayushi hindi commentary; Vol I; Vimanaa sthana; Rasavimana: Chapter 1, Verse 3. Varanasi: Chaukhambha Orientalia, 2009; p. 588

25. Vaidya Harish Chandra singh kushwaha, Reprint ed, Charaka Samhita; Ayurveda dipika's Ayushi hindi commentary; Vol I; Vimana sthana; Rogabhishagitiya adhyaya: Chapter 8, Verse 1617-18. Varanasi: Chaukhambha Orientalia, 2009; p. 665

26. Anna Moreswar Kunte, Reprint ed, Ashtanga hrudaya of Vaghata, Ayushkamiya adhyaya: Charpter 1, Verse 4 ,Varanasi, Chaukhamba Surabharati Prakashan; 2010; p. 15

27. Vaidya Harish Chandra singh kushwaha, Reprint ed, Charaka Samhita; Ayurveda dipika's Ayushi hindi commentary; Vol I; Vimana sthana; Rogabhishagjitiya adhyaya: Chapter 8, Verse 1617-18. Varanasi: Chaukhambha Orientalia, 2009; p. 687

Cite this article as:

Athikajan, Shreevathsa, Rajendra V. Interpretation of Ayurvedic terminologies from Biostatistical perspective in research. Int. J. Res. Ayurveda Pharm. 2013; 4(2):233-236 